\title{
Population genetic structure of Juniperus phoenicea (Cupressaceae) in the western Mediterranean Basin: gradient of diversity on a broad geographical scale
}

\author{
Artur Dzialuk • Malgorzata Mazur • \\ Krystyna Boratyńska • Jose M. Montserrat • \\ Angel Romo • Adam Boratyński
}

Received: 4 January 2011 / Accepted: 2 October 2011 /Published online: 9 November 2011

(C) The Author(s) 2011. This article is published with open access at Springerlink.com

\begin{abstract}
- Introduction, Material and Methods The genetic structure and diversity of ten natural populations of Juniperus phoenicea L. from the western part of the species range have been studied using random amplified polymorphic DNA (RAPD) markers.

- Results and discussion Among 10 analyzed primers only 3 reproduced consistently across successful PCR reactions and gave 45 loci. The percentage of polymorphic loci $(P)$ and Nei's heterozygosity $\left(H_{e}\right)$ have average values of $64.9 \%$ and 0.177 . The average expected heterozygosity of
\end{abstract}

Handling Editor: Luc Paques

A. Dzialuk

Department of Genetics, Kazimierz Wielki University,

Chodkiewicza 30,

85-064 Bydgoszcz, Poland

\section{Mazur}

Department of Botany, Kazimierz Wielki University,

Al. Ossolińskich 12,

85-093 Bydgoszcz, Poland

K. Boratyńska $\cdot$ A. Boratyński $(\square)$

Polish Academy of Sciences, Institute of Dendrology,

Parkowa 5,

63-036 Kórnik, Poland

e-mail: borata@man.poznan.pl

J. M. Montserrat

Institut de Cultura de Barcelona, Jardí Botànic de Barcelona,

C/ Font i Quer 2,

08038 Barcelona, Spain

\section{A. Romo}

Botanical Institute of Barcelona (CSIC-ICUB),

Passeig del Migdia s/n. Parc de Montjuïc,

08038 Barcelona, Spain particular populations positively correlate with latitude and negatively with altitude $(\tau=0.556, P=0.025 ; \tau=-0.494$, $P=0.047$, respectively). The proportion of genetic variation contributed by the differences between populations was low $\left(G_{\mathrm{ST}=} 0.056\right)$. The gene flow $\left(N_{\mathrm{m}}\right)$ has an average value of 4.2, and was higher in subsp. turbinata (7.3) than in subsp. phoenicea (4.1). Significant proportion of the variation $\left(\Phi_{\mathrm{ST}}=0.106\right)$ was attributable to differences among populations, as revealed in analysis of molecular variance analysis of pair-wise RAPD distances. No evidence for isolation by distance was detected in Mantel test on genetic $\left(\Phi_{\mathrm{ST}}\right)$ and geographic distances. European populations differed at a higher level from the African, subsp. phoenicea from turbinata $(3.97 \%$ and $3.14 \%$ of total variance, respectively). The significant level of differences between European and African populations can result from (1) the earlier divergence and considerably low level of gene flow between them, or (2) a different mutation rate within population of different continent.

- Conclusion The results suggest rather local forest economy with $J$. phoenicea, without seed exchange on large distance.

Keywords Biogeography Cupressaceae $\cdot$ Juniperus phoenicea $\cdot$ Plant variation $\cdot$ RAPD

\section{Introduction}

Juniperus phoenicea $\mathrm{L}$. is a small tree of about 8-12 $\mathrm{m}$ tall or sometimes only a shrub. It is a pioneer species with high light demands and relatively high resistance to a dry climate (Charco 2001; Quézel and Médail 2003). Its geographic range extends from the Canary Islands and the Atlas 
mountains in Africa in the West, to Jordan and Saudi Arabia in the East. The center of the species occurrence, however, covers the western part of the Mediterranean, especially the Iberian Peninsula and North-West Africa (Amaral Franco, 1986; Charco 2001; Farjon 2005). At the same time, the $J$. phoenicea contemporary geographical range is congruent with the area of several Pleistocene refugia of tertiary floras in the Mediterranean region (Médail and Diadema 2009). The highest taxonomic, morphological, biochemical, and genetic diversities of $J$. phoenicea were described from the Iberian Peninsula (Amaral Franco, 1986; Lebreton and Rivera 1989; Adams et al. 2002; Farjon 2005; Boratyński et al. 2009; Mazur et al. 2010). Two subspecies, the typical subsp. phoenicea and subsp. turbinata (Guss.) Nyman, Consp. Fl. Eur.: 676 (1881), were accepted there on the basis of taxonomical studies, reviewed and summarized lately by Farjon (2005), confirmed in the biometrical examinations (Mazur et al. 2010). Biochemical diversity correlated with diameter of cones (Lebreton and Rivera 1989) and also justified the separation of subsp. phoenicea and subsp. turbinata. Similarly, the strong differences were confirmed on the basis of 17 isoenzyme loci examination. Five of them appeared to be discriminated between the subspecies phoenicea and turbinata at a very high level (Boratyński et al. 2009).

The genetic variation of the genus Juniperus when using DNA markers has been investigated sporadically, but has made a valid contribution to the taxonomic position and relations among species and to geographic differentiation and phylogeography (e.g., Adams 1999, 2008; Adams et al. 2002, 2003; Terrab et al. 2008; Mao et al. 2010). The genetic variation of $J$. phoenicea with random amplified polymorphic DNA (RAPD) was tested on several individuals in the West and Central Mediterranean Basin (Adams et al. 2002), also confirming differences between subsp. phoenicea and subsp. turbinata.

The distinguishing of two subspecies in the area of Ibero-Moroccan refugial region (Amaral Franco, 1986; Farjon 2005) and results of investigation of the species variation (Lebreton and Riveira, 1989; Adams 1999; Lewandowski et al. 2000; Adams et al. 2002, 2003; Boratyński et al. 2009; Mazur et al. 2010) seems to indicate the existence of at least two centers there, isolated against the gene flow for a sufficiently long time in the past, an early ancestral divergence and the formation of morphological, biochemical, and genetic differences between them.

The landscape changes during last geological periods of Miocene, Pliocene, and Pleistocene had an important effect on the current taxonomic status, geographic distribution, and diversity of the Mediterranean biota
(Thompson 2005). Of particularly high influence was the Messinian Salinity Crisis, resulting in the connection of Europe and Africa (Krijgsman et al. 1999; Schneck et al. 2010; Jaromilo-Correa et al. 2010). The link between Eurasian and African tectonic plates was coincident with an extremely dry climate, but served as an intercontinental pathway between both sides of the Mediterranean (Krijgsman et al. 1999; Thompson 2005; Habel et al. 2009; Schneck et al. 2010). The separation of the Iberian Peninsula from Africa by the opening of the Strait of Gibraltar at the turn of the Miocene/Pliocene about 5 Myr BP (Krijgsman et al. 1999) has likely created an impermeable barrier for plant migration (Terrab et al. 2007, 2008; Habel et al. 2009).

The Pleistocene glacial/deglacial cycles also deeply influenced the plant migrations, flora composition, and species variation. The huge ice cap in the Pyrenees during LGM was a barrier for further re-colonization of deglaciated regions (Carrión 2002; Thompson 2005). Cycles of population isolation/expansion left detectable genetic signatures, leading to a structured distribution of genetic diversity in natural populations across Europe. However, the Mediterranean basin constitutes not only a major Pleistocene refugium, but also a crossroads of plant migrations and a center of active speciation (Thompson 2005; Terrab et al. 2007, 2008; Habel et al. 2009). In the Iberian Peninsula many populations followed "refugiawithin-refugia" scenario, which means they diverged without large geographical displacements producing intra-specific lineages often located in distinct allopatric refugia and exhibiting independent evolutionary histories (Gómez and Lunt 2007). The migration history of particular extant species depends also on their age and evolutionary rate. Generally, older species have a longer history and were exposed to a higher number of geologic events resulting in drastic climatic changes, which could be a reason for higher adaptive pressure, and consequently, could result in a higher level of variation and reveal higher differentiation. The early divergence of $J$. phoenicea from other junipers (Mao et al. 2010) and its morphological and genetic differentiation makes them a good subject to explain the patterns of migration and diversification of Mediterranean plants in the western part of the Mediterranean region.

The aim of the present study was to describe the distribution of genetic diversity and the geographical structure of variation of $J$. phoenicea in the western range of the species using random amplified polymorphic DNA markers. Despite well-known drawbacks (Hedrick 1992), this molecular technique is still widely used in investigations of population structure and differentiation of woody plants (Renau-Morata et al. 2005; Lise et al. 2007; Peng et al. 2007; Rajeb et al. 2010). To alleviate the bias related to dominant nature of RAPD's, we used new statistical 
approaches, particularly Bayesian clustering, the Monmonier algorithm, and genetic population parameter such as $\Phi_{\mathrm{ST}}$ (analysis of molecular variance (AMOVA)) for estimating population genetic parameters. Our specific objectives were to verify hypotheses that (a) the opening of the Gibraltar Straits at the end of MSC isolated European and African populations of J. phoenicea and was a reason of their present-day genetic variation; (b) that $J$. phoenicea survived LGM in different refugial areas in the western Mediterranean, which would also contribute to their present-day genetic variation; (c) to identify clusters of individuals representing different gene pools; and (d) to describe the phylogeographical relationships among populations of $J$. phoenicea. Because the climate changes are expected to be more pronounced in the Mediterranean Basin than in most of the other regions of the world, our results may also provide a baseline information for the conservation and sustainable management of the species.

\section{Material and methods}

\subsection{Plant material}

Sampling was carried out in 10 natural populations of $J$. phoenicea in the west Mediterranean region, each represented by $22-30$ individuals, except those from Andorra (Table 1). Six sample zones represented subsp. turbinata and four subsp. phoenicea. The twigs with leaves were collected randomly, without determination to the subspecies, only from cone bearing individuals, from the southfacing, well-isolated parts of their crowns at $1-2.5 \mathrm{~m}$ above ground level (Mazur et al. 2010).

Material sampled from each individual was dried at a temperature of about $20-30^{\circ} \mathrm{C}$, packed separately, and stored at about $20^{\circ} \mathrm{C}$ before analyses.

\subsection{DNA extraction}

Total genomic DNA was extracted from $50 \mathrm{mg}$ of leaves, which were ground to a fine powder in Eppendorf tubes using two steel beads and a shaking mill (Retsch MM301), following SDS protocol (Dellaporta et al. 1983). Final DNA concentration of $10 \mathrm{ng} / \mu \mathrm{l}$ was made by making appropriate dilution in water using a DNA calculator (BioPhotometr, Eppendorf). The quality of the extracted DNA was checked on $1 \%$ TBE agarose gels and samples yielding good quality and high molecular weight DNA were used for the experiment.

\subsection{RAPD amplification}

A set of 10 RAPD primers: 153, 184, 204, 212, 218, $239,244,249,250$, and 265 were screened with three individuals for each of the ten populations following the methodology given by Adams et al. (2002). From these, a subset of three RAPD markers that reproduced consistently across successful PCR reactions were used in this study (see Section 3).

PCR was performed in a volume of $10 \mathrm{ml}$ using a PTC200 thermocycler (MJ Research). Optimum reactions contained: $20 \mathrm{ng}$ of template DNA, $1 \times$ Qiagen PCR buffer, $2.0 \mathrm{mM} \mathrm{MgCl} 2,0.2 \mathrm{mM}$ each of dNTP, $0.35 \mu \mathrm{M}$ each primer, $5 \mu \mathrm{g} / \mu \mathrm{m}$ of BSA, and $0.25 \mathrm{U}$ of Taq Polymerase (Qiagen). RAPD products were separated on 2\% agarose gels in $1 \times$ TBE buffer, stained with $10 \mu \mathrm{g} / \mathrm{ml}$ ethidium bromide, and photographed over UV light. Their molecular weights were estimated using a 100-bp DNA lader (MBI Fermentas). A control PCR tube containing all components, but no genomic DNA, was run with each primer to check for contamination. Each sample was amplified and electrophoresed at least three times to ensure reproducibility of the banding pattern.

Table 1 Geographical location of ten populations of J. phoenicea (acronyms as in Boratyński et al. 2009)

\begin{tabular}{|c|c|c|c|c|c|c|}
\hline Acronym & Locality & Subsp. & Number of individuals & Longitude & Latitude & Altitude (m) \\
\hline AND 1 & Andorra, Coll de Jau near San Julia de Loria & phoenicea & 9 & E $1^{\circ} 28^{\prime}$ & $\mathrm{N} 42^{\circ} 27^{\prime}$ & 1,200 \\
\hline FRA 1 & France, Narbonne, near St. Pierre sur Mer & phoenicea & 28 & E $3^{\circ} 10^{\prime}$ & $\mathrm{N} 43^{\circ} 10^{\prime}$ & 50 \\
\hline MOR 2 & Morocco, High Atlas, Tizi-n-Tagalm Se of Miledt & turbinata & 26 & $\mathrm{~W} 4^{\circ} 34^{\prime}$ & $\mathrm{N} 32^{\circ} 37^{\prime}$ & 1,800 \\
\hline MOR 3 & Morocco, High Atlas, between Agouti and Azilal & turbinata & 29 & $\mathrm{~W} 6^{\circ} 29^{\prime}$ & $\mathrm{N} 31^{\circ} 38^{\prime}$ & 1,900 \\
\hline MOR 4 & $\begin{array}{l}\text { Morocco, High Atlas, slopes above Tagoundaft } \\
\text { between Tizi-n-Test and Asni }\end{array}$ & turbinata & 24 & $\mathrm{~W} 7^{\circ} 16^{\prime}$ & $\mathrm{N} 31^{\circ} 40^{\prime}$ & 1,650 \\
\hline MOR 5 & Morocco, High Atlas, Tizi-n-Tichka S of Taddert & turbinata & 28 & $\mathrm{~W} 1^{\circ} 14^{\prime}$ & $\mathrm{N} 31^{\circ} 17^{\prime}$ & 2,200 \\
\hline PORT 2 & Portugal, Algarve, Cabo de Pontal & turbinata & 30 & W $8^{\circ} 55^{\prime}$ & $\mathrm{N} 37^{\circ} 10^{\prime}$ & 25 \\
\hline SP 1 & Spain, Huelva, Playa de Matalascañas & turbinata & 26 & W $6^{\circ} 34^{\prime}$ & $\mathrm{N} 37^{\circ} 00^{\prime}$ & 20 \\
\hline SP 2 & Spain, Teruel, Sierra de Nogueruela E of Rubielos de Mora & phoenicea & 22 & W $0^{\circ} 40^{\prime}$ & $\mathrm{N} 40^{\circ} 24^{\prime}$ & 1,100 \\
\hline SP 3 & Spain, Teruel, Sierra de Valdancha, near Portella de Morella & phoenicea & 23 & $\mathrm{~W} 0^{\circ} 13^{\prime}$ & $\mathrm{N} 40^{\circ} 34^{\prime}$ & 1,100 \\
\hline
\end{tabular}




\subsection{Data analysis}

Amplified DNA marker bands were scored in a binary manner as either present (1) or absent (0) and entered into a binary data matrix. Bands/loci appearing in at least two of the three replicates were considered present. Bands whose sizes were within $10 \mathrm{bp}$ of each other were merged to account for any potential band migration discrepancies. To avoid possibility of underestimating diversity due to the dominant character of the RAPD markers we included large sample of trees and rejected bands with frequency higher than $1-(3 / N)$ where $N$ is the number of individuals under analysis (Lynch and Milligan 1994). In the absence of any previous information on its mating structure, drift, selection, or mutation, and recognizing that genetic equilibrium is primarily an ideal state that provides a baseline to measure genetic change against, we assumed Hardy-Weinberg equilibrium in $J$. phoenicea to estimate allele frequencies from presence/absence data.

\subsection{Statistical analyses}

The binary data matrix was analyzed using POPGENE version 1.32 (Yeh et al. 1999), AFLPsurv (Vekemans 2002) to calculate parameters in genetic diversity as follows: the percentage of polymorphic loci $(P)$, Nei's heterozygosity $\left(H_{\mathrm{e}}\right)$, mean heterozygosity within populations $\left(H_{\mathrm{S}}\right)$, total heterozygosity between populations $\left(H_{\mathrm{T}}\right)$, the diversity among populations $\left(D_{\mathrm{ST}}\right)$, degree of population differentiation $\left(G_{\mathrm{ST}}\right)$, and number of migrants per generation $\left(N_{\mathrm{m}}\right)$.

To estimate among-population genetic distance, band frequencies within each population were determined by using the AFLPsurv (Vekemans 2002) and then bootstrapped by using SEQBOOT in the program PHYLIP version 3.67 to generate 1,000 replicate data sets. The pairwise Nei genetic distance (Nei 1972) measures between populations were calculated from the bootstrapped band frequency data by using GENDIST in PHYLIP. The module NEIGHBOR was used to generate neighbor-joining trees and a majority rule consensus tree of the neighbor-joining trees was constructed by using the CONSENSE module in PHYLIP. Finally, neighbor-joining tree (NJ) was obtained by DRAWTREE of the same package (Felsenstein 1989). The degree of fit of a tree to a matrix of genetic distances was quantified both with bootstrapping (Felsenstein 2004) and $R^{2}$ value (Kalinowski 2009).

The genetic relationships among populations were further analyzed by the principal coordinate analysis ( $\mathrm{PCoA})$ based on Nei's (1972) genetic distance matrices using the program GenAlEx version 6 (Peakall and Smouse 2006).

To infer the partitioning of genetic variation within and among populations, an analysis of molecular variance (Excoffier et al. 1992) by using the program Arlequin was run. In hierarchical AMOVA, populations were grouped to assess the effect of geography and subspecies grouping. The significance was tested by resampling with $n=1,000$ randomizations. Pair-wise $\Phi_{\text {st }}$ values calculated by AMOVA were then used to illustrate differences between populations of $J$. phoenicea. The difference between Nei's heterozygosity $\left(H_{\mathrm{e}}\right)$ in Europe and Africa as well as in both subspecies were tested using a $t$ test, after confirming that data were normally distributed (Shapiro-Wilk's test). Pairwise correlations between Nei's heterozygosity $\left(H_{\mathrm{e}}\right)$ and geographic parameters (latitude, longitude, and altitude), were made using Kendall's $\tau$ estimate. The significance of the correlation was tested using a permutation procedure $(10,000$ permutations) with Past (Hammer et al. 2001).

Population structure was further analyzed with the Monmonier's maximum difference algorithm implemented in the software BARRIER 2.2 Manni et al. (2004). This analysis reveals the genetic discontinuities in genetic differentiation in relation to the populations' geographical arrangement. Barriers may thus be seen as "genetic breaks" between adjacent singular or groups of populations.

An alternative Bayesian-based clustering method was applied to infer genetic structure and define the number of clusters (gene pools) in the dataset using the software STRUCTURE 2.3.1 (Pritchard et al. 2000). Ten runs of STRUCTURE were done by setting the number of clusters $(K)$ from 1 to 10 (number of sampled populations). Each run consisted of a burn-in period of 2,500 steps followed by 10,000 Monte Carlo Markov Chain replicates, assuming an admixture model and correlated allele frequencies. No prior information was used to define the clusters. The $\Delta K$ statistic, based on the rate of change of log likelihood of data $[L(K)]$ between successive $K$ values was used to select the optimal $K$ following Evanno et al. (2005).

Finally, a Mantel correlation test (Mantel 1967) was applied to examine the presence of isolation by distance (Wright 1943), by using GenAlEx 6 (Peakall and Smouse 2006), to a matrix of pair-wise geographic and pair-wise genetic distances. Significance of the Mantel test was generated by using 1,000 permutations.

\section{Results}

\subsection{RAPD markers}

A pilot experiment was performed to evaluate primer suitability. From an initial screening of 10 primers, 3 were identified that produce clear and reproducible banding patterns, generating a total of 157 darkly staining bands. Of these markers, only $45(28.66 \%)$ were polymorphic, accurately scoreable, showed high readability, and were repeatedly visible in 10 populations of $J$. phoenicea. The 
three RAPD primers chosen for genotyping all 247 samples generated bands varying in size from 200 to 2,000 bp (Table 2).

\subsection{Genetic diversity}

Genetic diversity estimators are given in Table 3. The percentage of polymorphic loci $(P)$ ranged from $26.7 \%$ (population MOR 4) to 93.3\% (population SP 3), with an overall mean of $69.4 \%$. Values of Nei's heterozygosity $\left(H_{\mathrm{e}}\right)$ varied from 0.101 (population MOR 4) to 0.214 (population FRA 1), with a mean value of 0.177 . Although difference in heterozygosity between subspecies was not significant ( $t=1.676, P=0.1357$, Table 3$)$, the genetic diversity was much higher in the European populations $\left(H_{\mathrm{e}}=0.194\right)$, than in the African populations $\left(H_{\mathrm{e}}=0.141 ; t=3.124 ; P=0.008\right)$.

There was no correlation between the average expected heterozygosity and longitude (Kendall's $\tau=0.378$, $P=0.128)$, but there was a positive association with latitude and negative with altitude $(\tau=0.556, P=0.025 ; \tau=-0.494$, $P=0.047$, respectively).

Shanon's information index $(I)$ was slightly higher (0.320) than expected heterozygosity. Total heterozygosity $\left(H_{\mathrm{T}}\right)$ was 0.184 compared with an average heterozygosity within populations $\left(H_{\mathrm{S}}\right)$ of 0.173 and with a diversity between populations $\left(D_{\mathrm{ST}}\right)$ of 0.010 . The proportion of genetic variation contributed by the differences between populations $\left(G_{\mathrm{ST}}\right)$ is 0.056 , thus leaving $94.6 \%$ of the total genetic variation harbored within the populations analyzed. In opposition to other parameters, the estimate for the gene flow $\left(N_{\mathrm{m}}\right)$ was higher in $J$. phoenicea subsp. turbinata (7.3) than in subsp. phoenicea (4.1), while the mean was 4.2 .

A non-hierarchical AMOVA analysis of pair-wise RAPD distances indicated that although high variation $(89.39 \%)$ was found within populations, a significant proportion of the variation $\left(\Phi_{\mathrm{st}}=0.106\right)$ was attributable to differences among populations (Table 5). Pair-wise $\Phi_{\text {st }}$ values derived from AMOVA highlighted a large number of significant $(P=<0.05)$ differences between populations, when individual pairs of populations were compared (Table 4). A nested AMOVA revealed that geography (European vs. African populations) has a stronger effect on diversity

Table 2 RAPD primers used to generate multilocus profiles with DNA from $J$. phoenicea

\begin{tabular}{lll}
\hline RAPD primer & Nucleotide sequence $\left(5^{\prime} \rightarrow 3^{\prime}\right)$ & Fragment size range \\
\hline 249 & GCA TCT ACC G & $350-1,900$ \\
250 & CGA CAG TCC C & $200-2,000$ \\
265 & CAG CTG TTC A & $300-2,000$ \\
\hline
\end{tabular}

Table 3 Patterns of genetic diversity for $J$. phoenicea populations

\begin{tabular}{llllllll}
\hline Populations & $P$ & $H_{\mathrm{e}}$ & $H_{\mathrm{T}}$ & $H_{\mathrm{S}}$ & $D_{\mathrm{ST}}$ & $G_{\mathrm{ST}}$ & $N_{\mathrm{m}}$ \\
\hline \multicolumn{3}{l}{ Subsp. phoenicea } \\
SP 3 & 93.3 & 0.195 & & & & & \\
FRA 1 & 82.2 & 0.214 & & & & & \\
AND 1 & 51.1 & 0.164 & & & & & \\
SP 2 & 77.8 & 0.207 & & & & & \\
Mean & 76.1 & 0.195 & 0.207 & 0.195 & 0.012 & 0.058 & 4.1 \\
Subsp. turbinata & & & & & & & \\
MOR 5 & 48.9 & 0.124 & & & & & \\
PORT 2 & 75.6 & 0.202 & & & & & \\
MOR 2 & 75.6 & 0.157 & & & & & \\
MOR 3 & 68.9 & 0.183 & & & & & \\
MOR 4 & 26.7 & 0.101 & & & & & \\
SP 1 & 80.0 & 0.184 & & & & & \\
Mean & 62.6 & 0.159 & 0.164 & 0.159 & 0.005 & 0.033 & 7.3 \\
Overall mean & 69.4 & 0.177 & 0.184 & 0.173 & 0.010 & 0.056 & 4.2 \\
\hline
\end{tabular}

$P$ percentage of polymorphic loci, $H_{e}$ Nei's heterozygosity (genetic diversity), $H_{T}$ total heterozygosity between populations, $H_{S}$ mean heterozygosity within populations, $D_{S T}$ diversity among populations, $G_{S T}$ degree of population differentiation, $N_{m}$ number of migrants per generation

distribution among groups of populations studied than subspecies grouping (subsp. phoenicea vs. turbinata) (3.97\% and $3.14 \%$ of total variance, respectively).

\subsection{Phylogeographical analyses}

When Nei's (1972) genetic distance values were used to construct a NJ dendrogram in order to examine relationships between populations, two main clusters were identified, one grouping subspecies turbinata and the second clustering subspecies phoenicea (Fig. 1). The geographical least distant populations between both subspecies (SP 1 and SP 3) occupied an intermediate position between these two groups. The statistical confidence in the topology of the tree was confirmed by high bootstrap support and high $R^{2}$ value $(0.951$; Fig. 1$)$.

A more detailed pattern of variation was provided by the PCoA analysis, where the first three coordinates accounted for $64.93 \%$ of total variance $(31.64 \%$, $19.74 \%$, and $13.55 \%$, respectively). Three groups were apparent: the first including all but one populations of subsp. phoenicea (AND 1, FRA 1, and SP 2), the second including all but two populations of subsp. turbinata (MOR 2, MOR 3, MOR 4, and SP 1) and SP 3 of subsp. phoenicea, and the third grouping the western most populations of subsp. turbinata (PORT 2 and MOR 5; Fig. 2).

The population separations of the BARRIER analysis confirmed the strong genetic separation between both 
Table 4 Pair-wise $\Phi_{\mathrm{ST}}$ values calculated by AMOVA of RAPD variation illustrating differences between populations of $J$. phoenicea

\begin{tabular}{lllllllllll}
\hline & MOR 5 & PORT 2 & SP 3 & MOR 2 & MOR 3 & MOR 4 & SP 1 & FRA 1 & AND 1 & SP 2 \\
\hline MOR 5 & - & $*$ & $*$ & $*$ & $*$ & $*$ & $*$ & $*$ & $*$ & $*$ \\
PORT 2 & 0.112 & - & $*$ & $*$ & $*$ & $*$ & $*$ & $*$ & $*$ & $*$ \\
SP 3 & 0.117 & 0.060 & - & 0.018 & $*$ & $*$ & 0.001 & $*$ & $*$ & $*$ \\
MOR 2 & 0.089 & 0.075 & 0.026 & - & $*$ & $*$ & 0.012 & $*$ & $*$ & $*$ \\
MOR 3 & 0.095 & 0.103 & 0.060 & 0.055 & - & $*$ & $*$ & $*$ & $*$ & $*$ \\
MOR 4 & 0.114 & 0.132 & 0.108 & 0.062 & 0.113 & - & $*$ & $*$ & $*$ \\
SP 1 & 0.107 & 0.064 & 0.039 & 0.026 & 0.061 & 0.076 & - & $*$ & $*$ \\
FRA 1 & 0.180 & 0.120 & 0.085 & 0.114 & 0.125 & 0.157 & 0.066 & - & $*$ \\
AND 1 & 0.311 & 0.188 & 0.164 & 0.217 & 0.235 & 0.276 & 0.137 & 0.153 & - & $*$ \\
SP 2 & 0.201 & 0.126 & 0.081 & 0.114 & 0.133 & 0.158 & 0.073 & 0.045 & 0.115 \\
\hline
\end{tabular}

$\Phi_{\text {st }}$ values are given below the diagonal, and $P$ values are shown above diagonal

${ }^{*} P<0.001$ (significance test after 1,000 permutations)

subspecies (Fig. 3). The first three barriers separated populations of subsp. phoenicea and only the fourth separated population PORT 2 from subsp. turbinata. The Bayesian spatial analysis of population structure found an optimum of two clusters. Cluster 1, comprising samples from MOR $2(51 \%)$, MOR $3(62 \%)$, MOR $4(82 \%)$, and MOR $5(96 \%)$ was identified for the African population. The second cluster was constituted by AND 1 (97\%), FRA 1 (86\%), PORT $2(62 \%)$, SP 1 $(59 \%)$, SP $2(92 \%)$, and SP 3 (68\%; Fig. 4). No evidence for isolation by distance was detected.

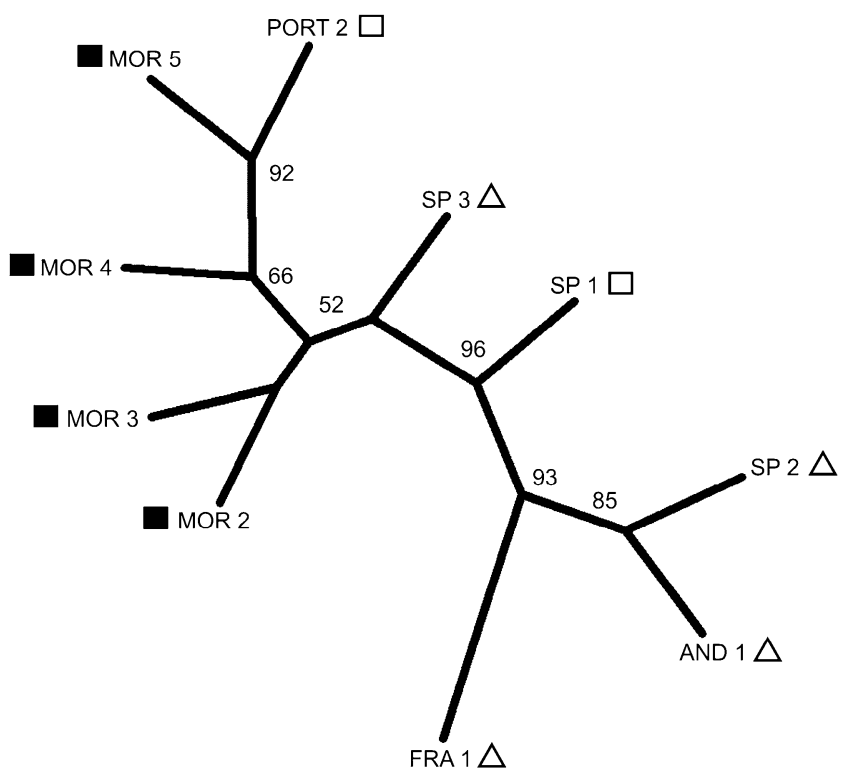

Fig. 1 Consensus UPGMA tree constructed using pair-wise Nei's (1972) genetic distance derived by RAPD analysis for populations of $J$. phoenicea. The percentage of 10,000 resampling runs supporting each node is shown. Squares J. phoenicea subsp. turbinata; triangles J. phoenicea subsp. phoenicea; open figures European populations; full figures African populations

\section{Discussion}

\subsection{Genetic diversity}

In this study an initial set of ten RAPD primers was screened to select those generating good amplification patterns. Three selected primers yielded 45 reproducible and polymorphic amplification products after amplification of ten natural populations of $J$. phoenicea from the western Mediterranean Basin. This number is lower than in similar studies based on dominant markers in other plant species, but similar to those observed recently in J. phoenicea using ISSR markers (Meloni et al. 2006).

The conifer species, as characterized by long life history (Farjon 2005) and wind-pollinating behavior, are generally the most genetically variable (Hamrick et al. 1992; Fady-Welterlen 2005). Our result is generally in line with many previous data on genetic differentiation of coniferous species using various markers, such as AFLPs, cpDNA, ISSRs, isoenzymes, and RAPDs (Jiménez et al. 2003; Fady-Welterlen 2005; Meloni et al. 2006; Terrab et al. 2007, 2008; Boratyński et al. 2009). The degree of population differentiation $\left(G_{\mathrm{ST}}=0.056 ; \Phi_{\mathrm{ST}}=0.106\right)$ is significant and similar to another reported for coniferous taxa (Petit et al. 2005). Among junipers, $\Phi_{\mathrm{ST}}$ value was found to be much higher for Juniperus thurifera on the AFLP markers (Terrab et al. 2008). The among population genetic distance calculated for five populations of $J$. phoenicea on the ISSR markers (Meloni et al. 2006) was also higher $\left(G_{S T}=0.12\right)$ than in our study (Table 3). The difference between our and Meloni et al.'s (2006) data could result from the different types of genetic markers used and the origin of compared populations from different areas. However, the structure of genetic diversity detected using RAPDs, calculated by AMOVA as more than $89 \%$ within and $10.6 \%$ among population (Table 5) 
Fig. 2 Principal coordinate analysis of the ten populations based on pair-wise Nei's (1972) genetic distances. Squares $J$. phoenicea; open figures European populations; full figures African populations phoenicea subsp. turbinata; triangles J. phoenicea subsp.
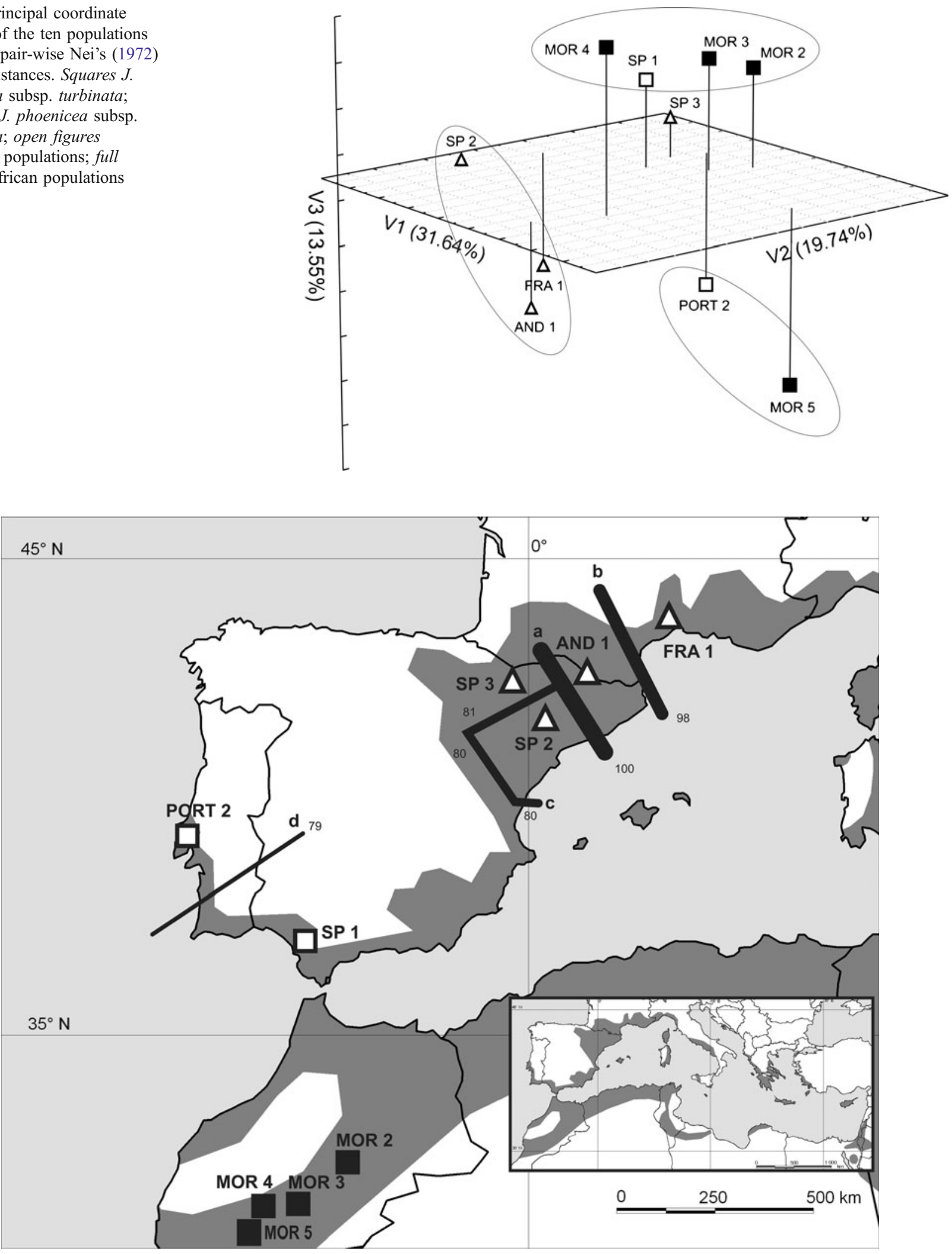

Fig. 3 Genetic boundaries $(a, b, c, d)$ obtained with Monmonier's maximum difference algorithm based on 1,000 bootstrap matrices of Nei's (1972) pair-wise genetic distances in J. phoenicea. The robustness of computed barriers is shown as a percentage of supporting resampled bootstrap matrices and the thickness of each edge. Squares represent $J$. phoenicea subsp. turbinata and triangles $J$. phoenicea subsp. phoenicea in both their native range (shaded area). Open and full figures show genetically different European and African populations according to the Bayesian-based clustering method implemented in STRUCTURE 
Fig. 4 Genetic relationships among $J$. phoenicea populations, estimated using STRUCTURE with $K=2$

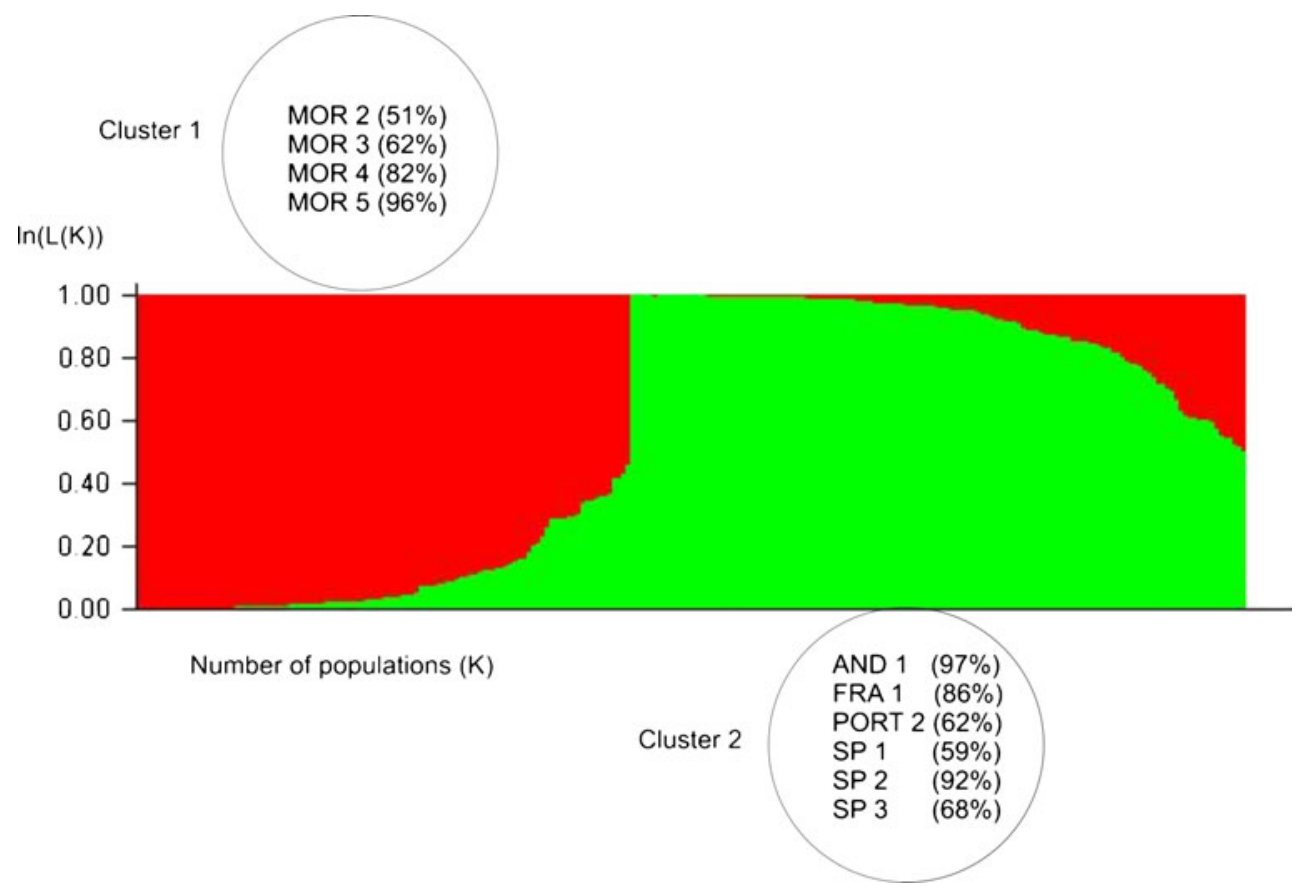

was lower than those found using ISSR (Meloni et al. 2006: 302) and isoenzymes (Boratyński et al. 2009: 166). This suggests the moderately infrequent gene flow among the examined populations of $J$. phoenicea, mostly as a result of discontinuous geographic range (Browicz and Zieliński 1982; Boratyński et al. 1992; Charco 2001; Quézel and Médail 2003).

The differences between $J$. phoenicea subsp. phoenicea and subsp. turbinata in our study covered only $3.14 \%$ of the total variation and can be recognized as small, but significant at a level of $P=0.02$ (Table 5). The differences between subspecies were found to be very high when comparing them using isoenzymatic markers. The five enzymatic systems were recognized as excepted reciprocally (Boratyński et al. 2009, Fig. 2: 167). In spite of the relatively low amount of genetic diversity differentiating the subspecies, they were quite clearly distinguished in principal coordinate analysis and consensus UPGMA tree constructed using pair-wise Nei's (1972) genetic distance analysis (Figs. 1 and 2). Our results are comparative with previous data described on RAPDs (Adams et al. 2002; Adams 2008), on biochemical compounds (Lebreton and Rivera 1989; Adams 2008), also on morphological characters (Mazur et al. 2010). Nevertheless, it shall be stressed that differences between subsp. phoenicea and turbinata were much more sharply outlined using markers other than RAPDs.

\subsection{Geographical and ecological remarks}

The genetic diversity of Mediterranean Gymnosperms is generally higher in the east than in the western part (Fady and Conord 2010) but, unfortunately, the area of our study covers only the western part of the region and probably that is why we did not detect this trend. Surprisingly, we detected a positive correlation of level of expected

Table 5 Analysis of molecular variance based on Nei's genetic distance (1972) among ten populations of J. phoenicea: (a) assuming no population structuring, (b) assuming population structuring based on isolation in Africa and Europe, (c) assuming subspecies grouping

\begin{tabular}{|c|c|c|c|c|c|c|}
\hline & Source of variation & d.f. & Sum of squares & Variance component & $\%$ of total variance & $P$ values \\
\hline \multirow[t]{2}{*}{ (a) } & Among populations & 9 & 207.57 & 0.670 & 10.61 & $<0.001$ \\
\hline & Within populations & 237 & $1,396.70$ & 5.893 & 89.39 & $<0.001$ \\
\hline \multirow[t]{3}{*}{ (b) } & Among regions & 1 & 49.58 & 0.267 & 3.97 & 0.005 \\
\hline & Among populations & 8 & 157.99 & 0.566 & 8.41 & $<0.001$ \\
\hline & Within populations & 237 & $1,396.70$ & 5.893 & 87.62 & $<0.001$ \\
\hline \multirow[t]{3}{*}{ (c) } & Among subsp. & 1 & 46.69 & 0.210 & 3.14 & 0.020 \\
\hline & Among populations & 8 & 160.88 & 0.584 & 8.74 & $<0.001$ \\
\hline & Within populations & 237 & $1,396.70$ & 5.893 & 88.13 & $<0.001$ \\
\hline
\end{tabular}


heterozygosity within populations with the geographic latitude. The Mediterranean and sub-Mediterranean species have embodied a generally higher genetic diversity within their southern populations, or did not reveal a statistical link between heterozygosity and latitudinal position (Fady and Conord 2010: 58). The pattern of distribution of J. phoenicea's genetic diversity can be connected with their migrations from north to south and to lower altitudes during cool, and recolonization during warm periods of the Quaternary, but this shall be verified on the broader range of material.

The lower values of expected heterozygosity in the higher locations can be explained by a general worsening of climatic conditions. The adaptation to lower temperatures and a shorter vegetation period in the mountains is frequently, but not always, the cause of decrease in genetic diversity (Chen et al. 2008; Fady and Conord 2010; Douaihy et al. 2011).

The genetic differences between subspecies and populations within subspecies did not show direct coincidence. The three first barriers which separate the most dissimilar populations practically divide the populations of subsp. phoenicea (Fig. 3). The separation confirms the intermediate character of population SP 3, which represented subsp. phoenicea but was placed among populations of subsp. turbinata, as shown on Figs. 1 and 2.

The geographic structure of genetic differentiation between ten examined populations reveals also significant differences between European and African populations (Table 5). This difference is higher than between subspecies, which can indicate (1) the earlier divergence and considerably low level of gene flow between European and African populations or (2) a different mutation rate within populations of different continents. The differences between the same or closely related taxa from Europe and Africa are frequently explained as resulting from the continent's isolation caused by the opening of the Gibraltar Straits after the Messinian Salinity Crisis, approximately $5 \mathrm{Ma}$ ago (Krijgsman et al. 1999). The high level of morphological differences between European and African populations of $J$. thurifera was a reason for exclusion of their subsp. africana (Romo and Boratyński 2007), found also at the genetic level using the RAPD and AFLP method (Jiménez et al. 2003; Terrab et al. 2008, respectively). Similar dependences have been found also in Abies species on the chloroplast DNA (Terrab et al. 2007), and other organisms (for review see Weiss and Ferrand, 2007; Terrab et al. 2008; Habel et al. 2009 and Ortiz et al. 2009).

Acknowledgments The study was partly sponsored by the Polish Committee for Scientific Research, grant no. 2P04C 03026 and partly by the Institute of Dendrology. The collection of plant material was made possible thanks to the cooperation between CSIC (Spanish Research Council) and PAS (Polish Academy of Sciences). We thank Ewa Sztupecka for her skilful technical assistance and Samuel Pyke for linguistic revision of the previous version of the manuscript.
Open Access This article is distributed under the terms of the Creative Commons Attribution Noncommercial License which permits any noncommercial use, distribution, and reproduction in any medium, provided the original author(s) and source are credited.

\section{References}

Adams RP (1999) Systematics of multi-seed eastern hemisphere Juniperus based on leaf essencial oils and RAPD DNA fingerprinting. Biochem Syst Ecol 27:709-727

Adams RP (2008) Junipers of the world: the genus Juniperus, 2nd edn. Trafford Publishing Co., Vancouver, 402p

Adams RP, Padney N, Rezzi S, Casanova J (2002) Geographic variation in the random amplified polymorphic DNAs (RAPDs) of Junierus phoenicea, J. p. var. canariensis, J. p . subsp. eu-mediterranea and J. p. var turbinata. Biochem Syst Ecol 30:223-229

Adams RP, Schwarzbach A, Pandey N (2003) The concordance of terpenoid, ISSR and RAPD markers, and ITS sequence data sets among genotypes: an example from Juniperus. Biochem Syst Ecol 31:375-387

Amaral Franco J do (1986) Juniperus L. In: Castroviejo S, Laínz M, López González G, Montserrat P, Muñoz Garmendia F, Paiva J and Villar L (eds), Flora iberica 1, Real Jardín Botanico, C.S.I.C., Madrid, pp. 181-188

Boratyński A, Browicz K, Zieliński J (1992) Chorology of trees and shrubs in Greece. Sorus, Poznań/Kórnik, 286 p

Boratyński A, Lewandowski A, Boratyńska K, Montserrat JM, Romo A (2009) High level of genetic differentiation of Juniperus phoenicea (Cupressaceae) in the Mediterranean region: geographic implications. Plant Syst Evol 277:163-172

Browicz K and Zieliński J (1982) Chorology of Trees and Shrubs in South-West Asia and Adjacent Regions. Polish Sci Publ, Warszawa - Poznań, $172 \mathrm{p}$

Carrión JS (2002) Patterns and processes of Late Quaternary environmental change in a montane region of southwestern Europe. Quat Sci Rev 21:2047-2066

Charco J (2001) Guía de los árboles y arbustos del norte de África. Agencia Española de Cooperación Internacional, Madrid, 671

Chen G, Wang Y, Zhao C, Korpelainen H, Li C (2008) Genetic diversity of Hippophaë rhamnoides populations at varying altitudes in the Wolong Natural Reserve of China as revealed by ISSR markers. Silvae Genet 57:29-36

Dellaporta S, Wood J, Hicks J (1983) A plant DNA minipreparation: version II. Mol Biol Rep 1:19-21

Douaihy B, Vendramin G, Machon N, Bou-Dagher KM (2011) Genetic diversity and population structure of Juniperus excelsa M. Bieb. in the east Mediterranean region. Ann Bot Plants 2011. doi:10.1093/aobpla/plr003

Evanno G, Regnaut S, Goudet J (2005) Detecting the number of cluster of individuals using the software STRUCTURE: a simulation study. Mol Ecol 14:2611-2620

Excoffier L, Smouse PE, Quattro JM (1992) Analysis of molecular variance inferred from metric distances among DNA haplotypes: application to human mitochondrial DNA restriction data. Genetics 131:479-491

Fady B, Conord C (2010) Macroecological patterns of species and genetic diversity in vascular plants of the Mediterranean basin. Diversity Distrib 16:53-64

Fady-Welterlen B (2005) Is there really more biodiversity in Mediterranean forest ecosystems? Taxon 54:905-910

Farjon A (2005) A monograph of Cupressaceae and Sciadopitys. Royal Botanic Gardens, Kew, 643 p 
Felsenstein J (1989) Phylip_Phylogeny Inference Package (Version 3.2). Cladistics 5:164-166

Felsenstein J (2004) Inferring phylogenies. Sinauer Associates Inc., Sunderland, $664 \mathrm{p}$

Gómez A, Lunt DH (2007) Refugia within refugia: patterns of phylogeographic concordance in the Iberian Peninsula. In: Weiss $\mathrm{S}$, Ferrand $\mathrm{N}$ (eds) Phylogeography in southern European refugia: evolutionary perspectives on the origins and conservation of European biodiversity. Springer, Amsterdam, pp 155-182

Habel JL, Dieker P, Schmitt T (2009) Biogeographical connections between the Maghreb and the Mediterranean peninsulas of southern Europe. Biol J Linn Soc 98:693-703

Hammer Ø, Harper DAT, Ryan PD (2001) PAST: paleontological statistics software package for education and data analysis. Palaeontol Electron 4

Hamrick JL, Godt MJW, Sherman-Broyles SL (1992) Factors influencing levels of genetic diversity in woody plant species. New Forest 6:95-124

Hedrick P (1992) Shooting the RAPDs. Nature 355:679-680

Jaromilo-Correa JP, Grivet D, Terrab A, Kurt Y, de-Lucas AI, Wahid N, Vendramin GG, González-Martínez SC (2010) The Strait of Gibraltar as a major biogeographic barrier in Mediterranean conifers: a comparative phylogeographic survey. Mol Ecol 19:5452-5468

Jiménez JF, Werner $\mathrm{O}$, Sánchez-Gómez $\mathrm{P}$, Fernández S, Guerra J (2003) Genetic variation and migration pathways of Juniperus thurifera L. (Cupressaceae) in the western Mediterranean region. Israel J. Plant Sci 51:11-22

Kalinowski ST (2009) How well do evolutionary trees describe genetic relationships between populations? Heredity 102: 506-513

Krijgsman W, Hilgen FJ, Raffi I, Sierro FJ, Wilson DS (1999) Chronology, causes and progression of the Messinian salinity crisis. Nature 400:652-655

Lebreton P, Rivera D (1989) Analyse du taxon Juniperus phoenicea L. sur des bases biochimiques et biomètriques. Natur Monspel Ser Bot 53:17-41

Lewandowski A, Samoćko J, Boratyński A, Mejnartowicz L (2000) Inheritance and linkage of allozymes in Juniperus phoenicea L. (Cupressaceae). Acta Soc Bot Pol 69:201-205

Lise Y, Kaya Z, Isık F, Sabuncu R, Kandemir I, Önde S (2007) The impact of over-exploitation on the genetic structure of Turkish red pine (Pinus brutia Ten.) populations determined by RAPD markers. Silva Fennica 41:211-220

Lynch M, Milligan G (1994) Analysis of population genetic structure with RAPD markers. Mol Ecol 3:91-99

Manni F, Guérard E, Heyer E (2004) Geographic patterns of (genetic, morphologic, linguistic) variation: how barriers can be detected by "Monmonier's algorithm". Human Biol 76:173-190

Mantel N (1967) The detection of disease clustering and a generalized regression approach. Cancer Res 27:209-220

Mao K, Hao G, Liu J, Adams RP, Milne RI (2010) Diversification and biogeography of Juniperus (Cupressaceae): variable diversification rates and multiple intercontinental dispersals. New Phytol 186:780-780

Mazur M, Klajbor K, Kielich M, Sowińska M, Romo A, Montserrat JM, Boratyński A (2010) Intra-specific differentiation of Juniperus phoenicea in the western Mediterranean region revealed in morphological multivariate analysis. Dendrobiol 63:21-31
Médail F, Diadema K (2009) Glacial refugia influence plant diversity patterns in the Mediterranean Basin. J Biogeogr 36:1333-1345

Meloni M, Perini D, Filigheddu R, Binelli G (2006) Genetic variation in five Mediterranean populations of Juniperus phoenicea as revealed by Intern-Simple Sequence Repeat (ISSR) markers. Ann Bot 97:299-304

Nei M (1972) Genetic distance between populations. Am Natur 106:283-292

Ortiz MA, Tremetsberger K, Stuessy T, Terrab A, García Castaño JL, Talavera S (2009) Phylogeographic patterns in Hypochaeris section Hypochaeris (Asteraceae, Lactuceae) of the western Mediterranean. J Biogeogr 36:1384-1397

Peakall R, Smouse PE (2006) GenAlEx: genetic analysis in Excel, population genetic software teaching and research. Mol Ecol Not 6:288-295

Peng XL, Zhao ChM, Wu GL, Liu JQ (2007) Genetic variation and phylogeographic history of Picea likiangensis revealed by RAPD markers. Trees 21:457-464

Petit RJ, Hampe A, Cheddadi R (2005) Climate changes and tree phylogeography in the Mediterranean. Taxon 54:877-885

Pritchard JK, Stephens M, Donnelly P (2000) Inference of population structure using multilocus genotype data. Genetics 155:945-959

Quézel P, Médail F (2003) Ecologie et biogeographie des forêts du bassin méditerranéen. Editions scientifiques et médicales Elsevier SAS, $571 \mathrm{p}$

Rajeb Ch, Messaoud Ch, Chograni H, Bejaoui A, Boulila A, Rejeb MN, Boussaid M (2010) Genetic diversity in Tunisian Crataegus azarolus L. var. aronia L. populations assessed using RAPD markers. Ann For Sci 67:512. doi:10.1051/forest/2010014

Renau-Morata B, Nebauer SG, Sales E, Allainguillaume J, Caligari P, Segura J (2005) Genetic diversity and structure of natural and managed populations of Cedrus atlantica (Pinaceae) assessed using Random Amplified Polymorphic DNA. Am J Bot 92:875-884

Romo A, Boratyński A (2007) Nomenclature note on Juniperus thurifera subsp. africana (Cupressaceae). Ann Bot Fenn 44:7275

Schneck R, Micheels A, Mosbrugger V (2010) Climate modelling sensitivity experiments for the Messinian salinity crisis. Palaeogeogr Palaeoclimat Palaeooecol 286:149-163

Terrab A, Talavera S, Arista M, Paun O, Stuessey FT, Tremetsberger K (2007) Genetic diversity and geographic structure at chloroplast microsatellites (cpSSR) in endangered West Mediterranean firs (Abies spp., Pinaceae). Taxon 56:409-416

Terrab A, Schönswetter P, Talavera S, Vela E, Stussey TE (2008) Rangewide phylogeography of Juniperus thurifera L., a presumptive keystone species of western Mediterranean vegetation during cold stages of the Pleistocene. Mol Phylogen Evol 48:94-102

Thompson JD (2005) Plant evolution in the Mediterranean. Oxford University Press Inc., New York, $293 \mathrm{p}$

Vekemans X (2002) AFLP-SURV version 1.0. Distributed by the author. Laboratoire de Génétique et Ecologie Végétale, Université Libre de Bruxelles, Belgium

Weiss S, Ferrad N (eds) (2007) Phylogeography of southern European refugia. Springer, Dordrecht, $377 \mathrm{p}$

Wright S (1943) Isolation by distance. Genetics 28:114-138

Yeh FC, Yang RC, Boyle T (1999) POPGENE Version 1.31: Microsoft Windows-Based Freeware for Population Genetic Analysis. Univ. of Alberta Press, Edmonton 